\title{
Management practices for control of ragwort species
}

\author{
Kirsten A. Leiss
}

Received: 21 January 2010/Accepted: 15 March 2010/Published online: 2 April 2010

(C) The Author(s) 2010. This article is published with open access at Springerlink.com

\begin{abstract}
The ragwort species common or tansy ragwort (Jacobaea vulgaris, formerly Senecio jacobaea), marsh ragwort (S. aquaticus), Oxford ragwort (S. squalidus) and hoary ragwort (S. erucifolius) are native in Europe, but invaded North America, Australia and New Zealand as weeds. The abundance of ragwort species is increasing in west-and central Europe. Ragwort species contain different groups of secondary plant compounds defending them against generalist herbivores, contributing to their success as weeds. They are mainly known for containing pyrrolizidine alkaloids, which are toxic to grazing cattle and other livestock causing considerable losses to agricultural revenue. Consequently, control of ragwort is obligatory by law in the UK, Ireland and Australia. Commonly used management practices to control ragwort include mechanical removal, grazing, pasture management, biological control and chemical control. In this review the biology of ragwort species is shortly described and the different management practices are discussed.
\end{abstract}

Keywords Jacobaea vulgaris $\cdot$ Senecio aquaticus . Mechanical control · Pasture management .

Biological control · Chemical control

K. A. Leiss ( $ه)$

Plant Ecology and Phytochemistry, Institute of Biology, Leiden University, Sylviusweg 72, 2333 BE Leiden,

The Netherlands

e-mail: K.A.Leiss@Biology.leidenuniv.nl

\section{Introduction}

The ragwort species common or tansy ragwort (Jacobaea vulgaris, formerly Senecio jacobaea), marsh ragwort (S. aquaticus), Oxford ragwort (S. squalidus) and hoary ragwort (S. erucifolius) are native members of the Asteraceae family in Europe, which invaded North America, Australia and New Zealand as weeds (Roberts and Pullin 2007). Ragwort species contain different groups of secondary plant compounds (Kirk et al. 2005; Leiss et al. 2009a) defending them against generalist herbivores, contributing to their success as weeds. Phenylpropanoids, flavanoids, the benzoquinone jacaranone and mainly pyrrolizidine alkaloids (PAs) are involved (Table 1). Especially the PAs defend ragwort against herbivorous insects. In addition PAs are toxic to grazing mammals like cattle, other livestock and horses (Duby 1975). Both freshly grazed ragwort plants as well as dried plants within feed such as silage and hay cause acute and chronic liver damage (Candrian et al. 1984). Ragwort is one of the most frequent causes of plant poisoning of livestock. It is responsible for over $90 \%$ of the complaints on injurious weeds in the United Kingdom (Crews et al. 2009). The Australian dairy industry estimated a loss of 4 Million Dollars per year due to ragwort poisoning of cattle (Roberts and Pullin 2006). Due to its carcinogenic properties (Prakash et al. 1999) the World Health Organization (WHO) considers PAs as contaminants in food as a threat to human health. Different European countries 


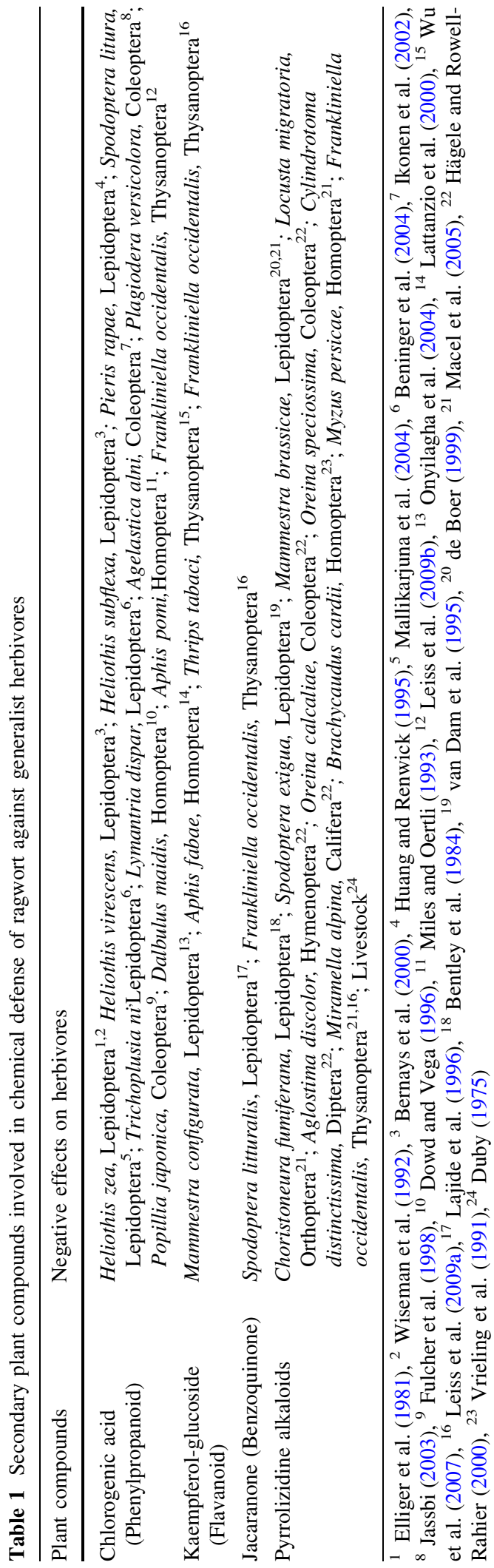

prescribed a maximimum level of $0.1 \mu \mathrm{g}$ as daily oral dose or $0.1 \mu \mathrm{g}$ per 100 food (Edgar et al. 2002). In feeding experiments with cows PA concentrations of up to $10 \mu \mathrm{g} / 100 \mathrm{ml}$ milk and up to $4 \mu \mathrm{g} / 100 \mathrm{~g}$ liver tissue have been detected (Dickinson et al. 1976; Candrian et al. 1991). Based on these experiments the expected possible concentration of PAs naturally occurring in cow's milk is estimated at a maximum of $0.2 \mu \mathrm{g} / 100 \mathrm{ml}$ (Candrian et al. 1991). Tests of commercial honeys determined PA concentrations of 0.19-12 $\mu \mathrm{g}$ PAs/100 g (Kempf et al. 2008) while honey of common ragwort contained up to $390 \mu \mathrm{g}$ PAs/100 g (Deinzer et al. 1997). Consequently, control of common ragwort is obligatory in some countries and is as such included in the legislation of the UK: "Weeds Act 1959" and "Ragwort Control Act 2003", Ireland: "Noxious Weed Act 1936", New Zealand: "Noxious Plant Act 1978", Australia: "Weed Management Act 1999", and Friesland, province of the Netherlands "Verordening Jakobskruiskruid 2007". However, ragwort species, especially the common and the marsh ragwort, remain a problem and their abundances are actually increasing in west- (Bezemer et al. 2006a) and central (Suter et al. 2007; Suter and Lüscher 2008) Europe. In this review the biology of ragwort species is shortly described and the different management practices to control them are discussed.

\section{Biology of ragwort species}

The most widespread of the ragwort species, as is expressed by its name, is the common or tansy ragwort. It is native to Europe from where it spread to North America, Australia and New Zealand (Roberts and Pullin 2007). It is abundant on light disturbed calcareous soils and dunes (Harper and Wood 1957) and poorly maintained pasture (Roberts and Pullin 2007). Common ragwort is usually a biennial plant, forming a rosette in the first year, while bolting and flowering in the second year (Harper and Wood 1957). However, it may become perennial when damage or cutting prevent flowering. Common ragwort is an early successional species that establishes during periods of disturbance (van der Meijden and van der Waals-Kooi 1979; Wardle 1987). Flowering is partially controlled by achievement of a certain minimum rosette size (van der Meijden and van der Waals-Kooi 1979). Common 
ragwort usually reproduces by seeds, whereby each plant can potentially produce thousands of seeds (Wardle 1987). Seed dispersion is usually restricted to short distances not exceeding $15 \mathrm{~m}$ (McEvoy and Cox 1987). Seeds mainly colonise spaces close to the mother plant. The horizontally growing rosette inhibits the surrounding vegetation, allowing the left space to be colonised by its own offspring (McEvoy 1984). Seeds just covered with soil germinate faster than surface sown seeds. Burial of seeds enforces seed dormancy (Wardle 1987). Also frost and drought may induce dormancy (van der Meijden and van der WaalsKooi 1979). Dormant seeds can persist in seed banks for up to 20 years (Crawley and Nachapong 1985). Viability of seeds after 6 years was still high (Thompson and Makepeace 1983). Germination is rapid (Cameron 1935) and germination rates are high (6090\%) depending on the season (Wardle 1987 and references therein). However, only a small proportion of seedlings and young plants will survive. Van der Meijden (1971) estimated that over $98 \%$ of the seed produced in a Dutch dune area failed to germinate, probably due to drought and frost. Also Forbes (1977a) reported that $57 \%$ of all germinating plants of a common ragwort population in Scotland died. Disturbance or injury promotes regrowth through roots and vegetative regeneration by crown buds. If the plant has sufficient food reserves regrowth occurs from the crown of the plant producing secondary flower shoots. However, seed production from these secondary flower shoots is usually less compared to undamaged plants (Cameron 1935). Regeneration may also occur from root buds. This mainly occurs in young roots of rosette plants, but roots of flowering plants can also regenerate this way (Poole and Cairns 1940).

Marsh ragwort originates in Europe from where it invaded the United States (USDA 2010), Australia (McLaren et al. 2000) and New Zealand (Sullivan 2006). It mainly inhabits wet grasslands such as meadows and marshes (Roberts and Pullin 2007). However, in Western and Central Europe it has established on farmland and pastures within the last 10 years (Suter and Lüscher 2008). It is a biennial species, which can become perennial when flowering is prevented by disturbance (Suter and Lüscher 2008). Each plant produces an abundant number of seeds, which are wind dispersed. Non-germinating seeds form long-lasting seed-banks, which can lead to recolonisation of marsh ragwort (Forbes 1976).
Oxford ragwort is a short-lived perennial native in Europe from where it spread to the United States (USDA 2010). It is locally distributed along disturbed habitats with open and dry conditions. These comprise cultivated ground as well as public sites such as railway banks, waysides and waste ground (Rag-Fork 2006).

Hoary ragwort is a stoloniferous perennial plant deriving from Europe. It has been reported to occur in the United States (USDA 2010). It grows on grassy waysides, waste ground and wood-margins, generally on clay soils (Rag-Fork 2006).

\section{Control of ragwort species}

Ragwort species should be controlled whenever they form problems as weeds as well as forming health risks for humans and animals. Therefore, farmers should check the development of ragwort species in agricultural fields and pasture regularly. Based on the potential spread of common ragwort seeds three risk zones have been defined: High risk if ragwort species are present in less than $50 \mathrm{~m}$ distance of a field or pasture, medium risk at the presence of ragwort plants between 50 and $100 \mathrm{~m}$ distance and low risk at a distance less than $100 \mathrm{~m}$ (Neumann et al. 2009). Where high risk is identified immediate action to control the spread of ragwort species should be taken. At medium risk a control policy should be established to ensure where a change from medium to high risk of spread can be anticipated, it is identified and dealt with in a timely and effective manner. At low risk no immediate action is required.

\section{Mechanical removal}

Mechanical control of common ragwort is difficult because the plant can regenerate from small root fragments (Wardle 1987). Effective manual control requires removal of the crown and all larger roots. It may, therefore, be only effective for seedlings and rosettes in contrast to bigger plants, which usually develop deep roots. However, disturbance of the soil also exposes buried seed to light which may lead to more germination.

Slashing or mowing is another form of mechanical removal. However, common ragwort has the ability 
within a few weeks to quickly grow back. The plants that grow back tend to switch to vegetative reproduction forming multiple crowns extending their lifespan (van der Meijden and van der Waals-Kooi 1979; Wardle 1987). Thus slashing or mowing per se is not sufficient for control of common ragwort (McLaren and Faithfull 2004).

Flaming killed $93 \%$ of common ragwort in the seeding stage whereby the burnt plants did not retain their viability (Wardle 1987).

Deep ploughing of non-agricultural land infested with common ragwort followed by cultivations in summer and autumn is another successful method to kill existing plants, regrowth and seedlings (McLaren and Faithfull 2004). However, cultivation is only recommended when carried out systematically and when suppressing common ragwort which is germinating from the soil seed bank.

\section{Grazing}

While cattle and horses will generally not feed on common ragwort, sheep do browse it, especially at the rosette stage (Cameron 1935). Sheep are the most resistant ruminants in regard to PA poisoning due bacterial decomposition of PAs in their rumen (Cheeke 1988). Older sheep eat the crown or growing portion of the rosette, while younger animals feed on the younger leaves only. Sheep may even develop a preference for common ragwort after they have acquired a taste for it (Poole and Cairns 1940). Amor et al. (1983) implied that sheep might reduce common ragwort reporting a mean ragwort ground cover of $5-6 \%$ in ungrazed pasture, of $1.7-2 \%$ in sheep grazed pasture and $7.8-13.2 \%$ in cattle-grazed pasture. In contrast, Sharrow and Mosher (1982) could not observe any differences in mortality of common ragwort between sheep- and cattle grazed pasture. However, in the cattle-grazed pasture significantly more common ragwort plants flowered before death compared to the sheep-grazed pasture. Thus sheep grazing leads to a lesser number of flowering and seeding plants. This may lead to a reduction in the seed bank over time. Especially in areas that are difficult to access grazing with sheep may be the best control option (McLaren and Faithfull 2004).

\section{Pasture management}

Ragwort species can be controlled by a pasture management promoting a dense, continuous and competitive pasture sward. This can be achieved through appropriate stocking densities and grazing regimes and/or irrigation and fertilization of pastures to promote their competitiveness.

The effect of grazing on the pasture cover greatly influenced the number of common ragwort seedlings in experimental sites in England (Cameron 1935). Continuous pasture inhibited germination of common ragwort seeds. Early in the life cycle the competitive balance between pasture plants and common ragwort is in favour of pasture (Wardle 1987). Later as the rosette of common ragwort establishes it competes well with grasses and clovers (Harper 1958). High species diversity will only suppress common ragwort when accompanied by high productivity (Bezemer et al. 2006b).

Continuous grazing leads to a significantly higher risk of infestations with ragwort species compared to rotational grazing (Suter et al. 2007). Due to the selective preferences of cattle continuous grazing often leads to unevenly grazed pasture (Fehmi et al. 2002). Overgrazed pasture leads to gaps in the sward in which seedlings of ragwort species can germinate and establish (Silvertown and Smith 1989). Indeed the fluctuation of temperature and moisture at these microsites can promote germination (Moretto and Distel 1998), while competition from other grasses is reduced. Overgrazing can also lead to damage of the sward by animal hooves. This especially occurs on steep inclinations and in wet soil conditions (Suter et al. 2007, Suter and Lüscher 2008). Undergrazed pasture provides conditions for establishment and completion of growth leading to seeding plants.

Fertilization of pastures with superphosphate or urea promoting a dense pasture sward reduced densitities of common ragwort (Thompson and Saunders 1986). Similarly, high nitrogen application, doubling nitrogen from 50 to $100 \mathrm{~kg}$ per hectare per year, reduced the risk of occurrence of common ragwort fivefold (Suter et al. 2007) and that of marsh ragwort threefold (Suter and Lüscher 2008). Together with high mowing frequencies high nitrogen applications promoted fast growing grass species, which resist frequent defoliation and which are strong competitors 
(Suter et al. 2007). Under such conditions the chance of common ragwort to germinate and establish is strongly impaired (Crawley and Nachapong 1985). Indeed, in meadows cut more then twice per year no common ragwort could be observed (Suter et al. 2007). Cutting common ragwort at the start or end of anthesis reduced the number of flowerheads by $87 \%$ (SiegristMaag et al. 2008). They recommended at least two cuts of common ragwort per year with the first mowing taking place when $50 \%$ of the plants start anthesis and the second mowing when half of the reestablished plants start anthesis again. A high mowing frequency though can lead to more mechanical damage, especially at higher inclinations and in wet conditions, resulting in gaps of the sward. Damage of the sward can also transport buried seed back to the surface and may lead to more germination of common ragwort. Marsh ragwort, however, can endure high cutting frequencies (Suter and Lüscher 2008). Therefore, the control of marsh ragwort should focus on the maintenance of dense swards and the prevention of sward damage instead.

Cut plants of ragwort species are usually incinerated, which is not environmentally friendly. Alternatively, Crews et al. (2009) demonstrated that composting common ragwort in black bin bags in the direct sunlight in the field leads to a breakdown of PAs within 4 weeks and a complete loss within 10 weeks.

\section{Biological control}

Classical biological weed control is based on the introduction of exotic control organisms from the geographical area of the weeds origin. These can be pathogens or insects.

Harper and Wood (1957) published a short list of fungi occurring on common ragwort in the United Kingdom. According to Wardle (1987) there are no fungi, which inflict significant damage on this plant. However, Bezemer et al. (2006b) suggested that soil organisms, in particular soil fungi, may determine the performance of common ragwort. They showed in a long-term field experiment with sown and unsown plots of common ragwort that the plant biomass increased dramatically over the first 4 years in the unsown plots but then declined thereafter being influenced by a negative plant-soil feedback. Negative feedbacks between plant and soil communities may develop when soil pathogens increase rapidly in the presence of their host, ultimately causing adverse plant conditions (Bever et al. 1997).

\section{Cinnabar moth (Tyria jacobaeae)}

The most prominent insect for control of common ragwort is the cinnabar moth (Tyria jacobaeae, Arctiidae). The larva of cinnabar moth is specialized on feeding on common ragwort. It uses the PAs contained for host detection, sequestering, and detoxifying them through N-oxidation (Naumann et al. 2002). Furthermore, PAs stimulate oviposition by females of the cinnabar moth (Macel and Vrieling 2003). The biology of the cinnabar moth has been reviewed by Dempster (1971, 1982). The cinnabar moth is univoltine. Adult moths emerge in late spring from overwintering pupae and oviposit clusters of eggs on the underside of leaves. Large rosettes or bolting plants are usually selected for oviposition. The first instar larvae skeletonise the leaves. During the following four instars the larvae move to the top of the plant consuming the leaves and developing floral parts. The larvae can thus completely defoliate common ragwort plants forcing older larvae to move to neighboring plants. Although larvae will feed on rosettes they do prefer flowering plants. After the fifth instar larvae pupate in litter or soil. Early assessments were that the cinnabar moth provided partial control of common ragwort (Hawkes and Johnson 1978). However, common ragwort can recover from defoliation (Cox and McEvoy 1983, Islam and Crawley 1983). Cinnabar moth from Europe was released as a biological control agent against common ragwort in the USA (McEvoy et al. 1991), Australia (McLaren et al. 2000) and New Zealand (Harman et al. 1990). However, many of these releases did not lead to an establishment of cinnabar moth. These failures were attributed to disease and parasitism (Field 1989), field predation (Cameron 1935; Dempster 1971; van der Meijden et al. 1991) and the importation of biotypes from Europe, which were ill adapted to the conditions overseas withstanding considerable desiccation in summer but suffering from water logging during winter. Water logging has been shown to be detrimental to the survival of cinnabar moth pupae (Dempster 1971). The cinnabar moth's limited power of dispersal has also been blamed for its failure to establish (Syrett 
1983). Several dispersal distances per generation have been recorded for the adult moths ranging from $20 \mathrm{~m}$ (Crawley and Gillman 1989) to over 300 m (Harrison et al. 1995). Mark-recapture data from Rudd and McEvoy (1996) suggested that the larger the scale of observation the greater the movement observed.

\section{Ragwort flea beetle (Longitarsus jacobaeae and L. flavicornis)}

The flea beetle Longitarsus jacobaeae (Alticinae) has been introduced as a biocontrol agent against common ragwort into the USA (Mc Evoy et al. 1991), Australia (McLaren et al. 2000) and New Zealand (Dastgheib 2005). In the case of Australia the species introduced was later identified to be Longitarsus flavicornis (Field 1989). Also the flea beetle is an insect specialized on common ragwort since it is able to sequester PAs and store them as non-toxic N-oxides (Narberhaus et al. 2003, 2004).

The flea beetle is univoltine (Ireson et al. 1991). Adults emerge from pupae overwintering in the soil. They feed by rasping through the leaves leaving a characteristic pattern of shot holes (Windig 1991). The eggs are laid in the soil surrounding a plant. The major damage to the plant is caused by the larvae boring into leaf petioles and roots. Here they feed throughout the winter passing through three instars completing development in spring (Ireson et al. 1991). The larvae are mobile and will move away from dying plants. In the USA females undergo a summer aestivation, which delays oviposition for up to 5 months with an intense feeding period 2-8 weeks before egg laying (Frick 1970).

Flea beetles released in the USA reduced the number of vegetative plants of common ragwort by $95 \%$ and flower production by $39 \%$ (James et al. 1992). Flea beetles introduced into Australia were able to reduce densities of common ragwort by as much as 90\% (Ireson et al. 1991, 2000).

The effect of the flea beetle is complementary to that of the cinnabar moth. The larvae of the cinnabar moth feed on the flowers and leaves in summer. The adults of the flea beetle feed on leaves, while the larvae feed on roots and leaf petioles during autumn, winter and spring. The combination of these two biocontrol agents reduced common ragwort to less than $1 \%$ of its former abundance in Oregon (McEvoy et al. 1991). A meta-analysis of the effectiveness of biological control of ragwort species, using available publications up to the year 2004, concluded that indeed the combination of the cinnabar moth with the flea beetle was most effective with an average reduction in densities of common ragwort of $99.5 \%$ (Roberts and Pullin 2007). The cinnabar moth alone reduced the number of common ragwort plants by $52.3 \%$ on average and the flea beetle alone by $96.5 \%$.

\section{Ragwort stem and crown boring moth (Cochylis atricapitana)}

The ragwort stem and crown boring moth Cochylis atricapitana (Tortricidae) from Europe was released as a biocontrol agent of common ragwort in Australia (McLaren et al. 2000) and New Zealand (Gourlay 2007a). The moth can produce 2-3 generations per season with adults appearing in spring and autumn. Eggs are laid individually on the undersides of leaves. The hatching larvae begin mining into the plant tissue boring into crowns and stems of plants (McLaren 1992). The moth passes through five instars. Pupation takes place in the plant or surrounding plant soil. Larval feeding severely damages the root crowns of rosette plants and can cause their death. A $40 \%$ reduction in plant height of flowering plants and a significant reduction in both size and survival of rosettes have been observed (McLaren et al. 2000; Gourlay 2007a).

\section{Ragwort plume moth (Platyptilia isodactyla)}

The most recent biocontrol agent used is the ragwort plume moth Platyptilia isodactyla (Pterophoridae), which has been released in 1999 into Australia (Faithful et al. 1999) and in 2006 into New Zealand (Gourlay 2007b). Its most common host is marsh ragwort (Emmet and Heath 1989). The plume moth has 2-3 generations per year with adults flying in spring and autumn (Emmet and Heath 1989). Eggs are mainly laid on the underside of leaves. Hatching larvae tunnel down into the crown of rosettes or into the stalks of flowering plants where they pass through five instars (McLaren et al. 2000). They complete development by pupation inside curled leaves or in the soil surrounding the plant (Masri 1995). Larval 
feeding severely damages the crown of the plant with only two to three larvae being capable of killing a whole plant (McLaren et al. 2000). Densities of marsh ragwort have been reduced by $60-80 \%$ (Gourlay 2007b).

\section{Chemical control}

Different herbicides have been tried on ragwort species with varying degrees of success. Generally, young rosettes are easier to be controlled compared to older plants. The 2,4-dichlorophenoxyacetic acid $(2,4-D)$ works well on younger plants but performs poorly on late rosettes, budding or flowering plants (Black 1976). Picloram showed a better performance than 2,4-D (Thompson 1974, 1977) and 2-methyl4-chlorophenoxyacetic acid (MCPA) (Thompson and Saunders 1984). On young plants glyphosate (Makepeace and Thompson 1982) performed less well compared to 2,4-D and Picloram, while it performed better on flowering plants (Thompson 1983). A combination of 2,4-D, MCPA and 2,4,5-trichlorophenoxyacetic acid $(2,4,5,-\mathrm{T})$ controlled more than $98 \%$ of common ragwort (Forbes 1978). A mixture of 2,4-D and MCPA achieved 90\% control of common ragwort as did a mixture of dicamba and MCPA, while up to $100 \%$ control was achieved with a mixture of Fluroxypr and Aminopyralid (Neumann et al. 2009). Asulam successfully controlled marsh ragwort (Forbes 1977b). A significant reduction of populations of common ragwort densities have further been reported using different herbicides such as Hexazinone (James and Mortimer 1983), Flazasulfuron (James et al. 1997), Clopyralid (Whitson et al. 1986; Clay and Dixon 1998), Tricopyr and Fluroxypr (Dixon and Clay 2001) as well as Amidosulfuron, Pyridate and Tribenuron (Dixon and Clay 2004). Meta-analysis of the effectiveness of herbicide application to control ragwort species, including published data up to the year 2004, showed that 2,4-D, MCPA and glyphosate are effective against common ragwort, while Asulam is effective against marsh ragwort (Roberts and Pulin 2007).

However, chemical control in pastures can cause harmful side effects influencing pasture growth, especially white and red clover (Black 1976). Furthermore, herbicide applications are problematic in nature con- servations sites. Therefore, mature plants, which require higher rates of herbicides should be selectively treated with localized spot-sprays (Thompson 1977, 1983; Forbes 1982). Another approach to minimize damage of pasture by applying chemical control is the Australian "Mitchell technique" (Watt 1987). Mature plants are allowed to complete their life cycle in an ungrazed situation so that the plants die naturally. Subsequent establishment will then entirely be based on seedling emergence. Seedlings are controlled by herbicide application together with grazing and maintenance of a dense pasture sward.

In order to integrate chemical and biological control of common ragwort the effect of herbicides on the ragwort flea beetle has been studied. Data indicated that at field rates clopylarid, glyphosate, MCPA and mixtures of 2,4-D and picloram or dicamba had no lethal effects on adult flea beetles (Dastgheib 2005; Gourlay 2007c). However, sub-lethal effects especially on oviposition were not excluded. No information is available on the impact of herbicides on the remaining biocontrol agents.

\section{Conclusion}

Ragwort species, especially the common and the marsh ragwort still remain a weed problem. Their spread within Europe is even increasing (Suter et al. 2007; Suter and Lüscher 2008). This increase is related to modifications in agricultural management. Farming has concentrated on bigger farms with less manpower leading to less intensive pasture management. Furthermore, ragwort species invade pastures through nature conservation and nature compensation areas, through ruderal areas with a high level of disturbance and through the public domain such as roadsides and railway banks (Suter et al. 2007). A successful control of ragwort species needs to be based on scientific findings to be implemented by a combined effort of farmers and public authorities. However, as pointed out by Roberts and Pullin (2007) the availability of scientific information on weed control to farmers, land manager and nature conservation practitioners is problematic. Besides scientific publications other forms of communications such as newsletters and more recently free access websites are important. 
Open Access This article is distributed under the terms of the Creative Commons Attribution Noncommercial License which permits any noncommercial use, distribution, and reproduction in any medium, provided the original author(s) and source are credited.

\section{References}

Amor RL, Lane DW, Jackson KW (1983) Observations on the influence of grazing by sheep or cattle on the density and cover of ragwort. Aust Weeds 2:94-95

Beninger CW, Abou-Zaid MM, Kistner ALE, Hallett RH, Iqbal MJ, Grodzinski B, Hall JC (2004) A flavanone and two phenolic acids from Crysanthemum morifolium with phytotoxic and insect growth regulating activity. J Chem Ecol 30:589-606

Bentley M, Leonard D, Stoddard DE, Zalkow LH (1984) Pryrolozidine alkaloids as larval feeding deterrents for spruce budworm, Choristoneura fumiferana (Lepidoptera: Tortiricidae). Ann Entomol Soc Am 77:393-397

Bernays EA, Oppenheim S, Chapman RF, Kwon H, Gould F (2000) Taste sensitivity of insect herbivores to deterrents is greater in specialists than in generalists: a behavioral test of the hypothesis with two closely related caterpillars. J Chem Ecol 26:547-563

Bever JD, Westover KM, Antonovics J (1997) Incorporating the soil community into plant population dynamics: the utility of the feedback approach. J Ecol 85:561-573

Bezemer M, van der Putten W, Rienks F (2006a) Niets doen loont bij Jakobskruiskruidplaag. De levende Natuur 107:104-107

Bezemer M, Harvey JA, Kowalchuk GA, Korpershoek H, van der Putten WH (2006b) Interplay between Senecio jacobaea and plant, soil and aboveground insect community. Ecology 87:2002-2013

Black WN (1976) Effects of herbicide rates and time of application of the control of tansy ragwort in pastures. Can J Plant Sci 56:605-610

Cameron E (1935) A study on the natural control of ragwort (Senecio jacobaea). J Ecol 23:265-322

Candrian U, Lüthi J, Schmid P, Schlatter C (1984) Stability of pyrrolizidine alkaloids in hay and silage. J Agric Food Chem 32:935-937

Candrian U, Zweifel U, Lüthi J, Schmid P, Schlatter C (1991) Transfer of orally administered $\left[{ }^{3} \mathrm{H}\right]$ Seneciophylline into cow's milk. J Agric Food Chem 39:930-933

Cheeke PR (1988) Toxicity and metabolism of pyrrolizidine alkaloids. J Anim Sci 66:2343-2350

Clay DV, Dixon FL (1998) The susceptibility of compositae weed species to clopyralid: Tests of agrochemcials and cultivars. Suppl Ann Appl Biol 132:32-33

Cox CS, McEvoy PB (1983) Effect of summer moisture stress on the capacity of tansy ragwort (Senecio jacobaea) to compensate for defoliation by the cinnabar moth (Tyria jacobaeae). J Appl Ecol 20:225-234

Crawley MJ, Gillman MP (1989) Population dynamics of cinnabar moth and ragwort in grassland. J Anim Ecol 58:1035-1050
Crawley MJ, Nachapong M (1985) The establishment of seedlings from primary and regrowth seeds of ragwort (Senecio jacobaea). J Ecol 73:255-262

Crews C, Driffield M, Berthiller F, Krska R (2009) Loss of pyrrolizidine alkaloids on decomposition of ragwort (Senecio jacobaea) as measured by LC-TOF-MS. J Agric Food Chem 57:3669-3673

Dastgheib F (2005) A study of the effect of selected pesticides on ragwort flea beetle. IWM consultancy report for the West Coast Ragwort Control Trust New Zealand, pp 1-11

de Boer NJ (1999) Pyrrolizidine alkaloid distribution in Senecio jacobaea rosettes minimises losses to generalist feeding. Entomol Exp Appl 91:169-173

Deinzer ML, Thomson PA, Burgett DM, Isaacson DL (1997) Pyrrolizidine alkaloids: their occurrence in honey from tansy ragwort (Senecio jacobaea L.). Science 195:497-499

Dempster JP (1971) The population ecology of the cinnabar moth, Tyria jacobaeae L. (Lepidoptera: Arctiidae). Oecologia 7:26-67

Demptser JP (1982) The ecology of the cinnabar moth Tyria jacobaeae L. (Lepidoptera, Arctiidae). Adv Ecol Res 12:1-36

Dickinson JO, Cooke MP, King RR, Mohamed PA (1976) Milk transfer of pyrrolizidine alkaloids in cattle. J Am Vet Med Assoc 169:1192-1196

Dixon FL, Clay DV (2001) Effect of synthetic and naturalproduct herbicides on Senecio jacobaea (common ragwort). In: Proceedings of the 2001 British Crop Protection Council Conference-Weeds, pp 721-726

Dixon FL, Clay DV (2004) Effect of herbicides applied preand post-emergence on forestry weeds grown from seed. Crop Prot 23:713-721

Dowd PF, Vega FE (1996) Enzymatic oxidation products of allelochemicals as a basis for resistance against insects: effects on the corn leafhopper Dalbulus maidis. Nat Toxins 4:85-91

Duby GD (1975) Tansy ragwort: a toxic threat to livestock. Mod Vet Pract 56:184-188

Edgar JA, Roeder E, Molyneux RJ (2002) Honey from plants containing pyrrolizidine alkaloids: a potential threat to health. J Agric Food Chem 50:2719-2730

Elliger CA, Wong Y, Chan BG, JR Waiss AC (1981) Growth inhibitors in tomato (Lycopersicon) to tomato fruitworm (Heliothis zea). J Chem Ecol 7:753-758

Emmet AM, Heath J (1989) The moths and butterflies of Great Britain and Ireland. vol 7 part 1. Harley Books

Faithful I, Newnham M, Green K, Freeman N (1999) Biological control of ragwort with the ragwort plume moth. Landcare Note LC0166. Department of Natural Resources and Environment, State of Victoria

Fehmi JS, Karn JF, Ries RE, Hendrickson JR, Hanson JD (2002) Cattle grazing behaviour with season-long free-choice access to four forage types. Appl Anim Behav Sci 78:29-42

Field RP (1989) Progress towards biological control of ragwort in Australia. In: Delfosse ES (ed) Proceedings of the 7th International Symposium on Biological Control of Weeds, Rome, 1988, pp 315-322

Forbes JC (1976) Influence of management and environmental factors on the distribution of the marsh ragwort (Senecio aquaticus Huds.) in agricultural grassland in Orkney. J Appl Ecol 13:985-990 
Forbes JC (1977a) Population flux and mortality in ragwort (Senecio jacobaea L.) infestation. Weed Res 17:387-391

Forbes JC (1977b) Chemical control of marsh ragwort (Senecio aquaticus Huds.) in established grassland. Weed Res $17: 247-250$

Forbes JC (1978) Control of Senecio jacobaea L. (ragwort) by autumn or spring herbicide applications. Weed Res 18:109-110

Forbes JC (1982) Evaluating herbicides for selective control of Senecio jacobaea in grass/clover swards. In: Proceedings of the 1982 British Crop Protection Conference-Weeds, pp 375-379

Frick KE (1970) Longitarsus jacobaeae (Coleoptera: Chrysomelidae), a flea beetle for the biological control of tansy ragwort. 1. Host specificity studies. Ann Entomol Soc Am 63:284-296

Fulcher AF, Ranney TG, Burton JD, Walgenbach JF, Danehower DA (1998) Role of foliar phenolics in host plant resistance of Malus taxa to adult Japanese beetle. Hortscience 33:862-865

Gourlay H (2007a) Ragwort crown-boring moth. Landcare Research, New Zealand Information Note

Gourlay H (2007b) Ragwort plume moth. Landcare Research, New Zealand Information Note

Gourlay H (2007c) Ragwort biocontrol agents \& sprays. Landcare Research, New Zealand Information Note

Hägele BF, Rowell-Rahier M (2000) Choice, performance and heritability of performance of specialist and generalist insect herbivores towards cacalol and seneciophylline, two allelochemicals of Adenostyles alpine (Asteraceae). J Evol Biol 13:131-142

Harman M, Dymock JJ, Syrett P (1990) Temperature and development of cinnabar moth, Tyria jacobaeae (Lepidoptera: Arctiidae), in New Zealand. In: Delfosse ES (ed) Proceedings of the VII International Symposium on Biological Control of Weeds, Rome, 1989, pp 339-346

Harper JL (1958) The ecology of ragwort (Senecio jacobaea) with especial reference to control. Herbage Abstr 28:151-157

Harper JL, Wood WA (1957) Senecio jacobaea L. J Ecol 45:617-637

Harrison S, Thomas D, Lewinsohn TM (1995) Testing a metapopulation model of coexistence in the insect community on ragwort (Senecio jacobaea). Am Nat 145:546-562

Hawkes RB, Johnson GR (1978) Longitarus jacobaeae aids moth in the biological control of tansy ragwort. In: Freeman TE (ed) Proceedings of the IV International Symposium on the Biological Control of Weeds, Gainesville, pp 193-196

Huang XP, Renwick JAA (1995) Chemical and experimental basis for rejection of Tropaeolum majus by Pieris rapae larvae. J Chem Ecol 21:1601-1617

Ikonen A, Tahvanainen J, Roininen H (2002) Phenolic secondary compounds as determinants of the host plant preferences of the leaf beetle Agelastica alni. Chemoecology 12:125-131

Ireson JE, Friend DA, Holloway RJ, Paterson SC (1991) Biology of Longitarsus flavicornis (Stephens) (Coleoptera: Chrysomelidae) and its effectiveness in controlling ragwort (Senecio jacobaea L.) in Tasmania. J Aust Entomol Soc 30:129-141
Ireson JE, Leighton SM, Holloway RJ, Chatteron WS (2000) Establishment and redistribution of Longitarsus flavicornis (Stephens) (Coleoptera: Chrysomelidae) for the biological control of ragwort (Senecio jacobaeae L.) in Tasmania. Aust Entomol 39:42-46

Islam Z, Crawley MJ (1983) Compensation and regrowth in ragwort (Senecio jacobaea) attacked by cinnabar moth (Tyria jacobeaea). J Ecol 71:829-843

James TK, Mortimer J (1983) Control of ragwort and nodding thistle in lucerne with hexazinone. In: Proceedings of the 36th New Zealand Weed and Pest Control Conference, pp 17-20

James RR, Mc Evoy PB, Cox CS (1992) Combining the cinnabar moth (Tyria jacobaeae) and the ragwort flea beetle (Longitarsus jacobaea) for control of ragwort (Senecio jacobaea): an experimental analysis. J Appl Ecol 29:589-596

James TK, Rahman A, DeJong P (1997) Flazasulforon for control of ragwort (Senecio jacobaea) in pasture. In: Proceedings of the 15th New Zealand Plant Protection Conference, pp 477-481

Jassbi AR (2003) Secondary metabolites as stimulants and antifeedants of Salix integra for the leaf beetle Plagiodera versicolora. Z Naturforsch Teil C-J Biosci 58:573-579

Kempf M, Beuerle T, Bühringer M, Denner M, Trost D, von der Ohe K, Bhavanam VBR, Schreier P (2008) Pyrrolizidine alkaloids in honey: risk analysis by gas chromatographymass spectrometry. Mol Nutr Food Res 52:1193-1200

Kirk H, Choi YH, Kim HK, Verpoorte R, van der Meijden E (2005) Comparing metabolomes: the chemical consequences of hybridization in plants. New Phytol 167: 613-622

Lajide L, Escoubas P, Mizutani J (1996) Cyclohexadienonesinsect growth inhibition from the foliar surface and tissue extracts of Senecio cannabifolius. Experientia 52:259-263

Lattanzio V, Arpaia S, Cardinali A, di Venere D, Linsalata V (2000) Role of endogenous flavanoids in resistance mechanism of Vigna to aphids. J Agric Food Chem 48:5316-5320

Leiss KA, Choi YH, Abdel-Farid IB, Verpoorte R, Klinkhamer PGL (2009a) NMR metabolomics of thrips (Frankliniella occidentalis) resistance in Senecio hybrids. J Chem Ecol 35:219-229

Leiss KA, Maltese F, Choi YH, Verpoorte R, Klinkhamer PGL (2009b) Identification of chlorogenic acid as a resistance factor for thrips in chrysanthemum. Plant Physiol 150:1567-1575

Macel M, Vrieling K (2003) Pyrrolizidine alkaloids as oviposition stimulans for the cinnabar moth, Tyria jacobaeae. J Chem Ecol 29:1435-1446

Macel M, Bruinsma M, Dijkstra SM, Ooijendijk T, Niemeyer HM, Klinkhamer PGL (2005) Differences in effects of pyrrolizidine alkaloids on five generalist insect herbivore species. J Chem Ecol 31:1493-1508

Makepeace W, Thompson A (1982) Ragwort control using a rope wick applicator. In: Proceedings of the 35th New Zealand Weed and Pest Control Conference, pp 256-260

Mallikarjuna N, Kranthi KR, Jadhav DR, Kranthi S, Chandra S (2004) Influence of foliar chemical compounds on the development of Spodoptera litura (Fab.) in interspecific derivatives of groundnut. J Appl Entomol 128:321-328 
Masri R (1995) Life history studies on Platypilla isodactyla a potential biological control agent of ragwort. Honours thesis, La Trobe University, Melbourne

McEvoy (1984) Seedling dispersal and the persistence of ragwort Senecio jacobaea (Compositae) in a grassland dominated by perennial species. Oikos 42:138-143

McEvoy PB, Cox CS (1987) Wind dispersal distances in dimorphic achenes of ragwort, Senecio jacobaea. Ecology 68:2006-2015

McEvoy P, Cox C, Coombs E (1991) Successful biological control of ragwort, Senecio jacobaea, by introduced insects in Oregon. Ecol Appl 1:430-442

McLaren DA (1992) Observations on the life cycle and establishment of Cochylis atricapitana (Lep: Cochylidae), a moth for biological control of Senecio jacobaeae in Australia. Entomophaga 37:641-648

McLaren D, Faithfull I (2004) Ragwort-Management. Landcare Note LC0382. Department of Sustainability and Environment, State of Victoria

McLaren DA, Ireson JE, Kwong RM (2000) Biological control of ragwort (Senecio jacobaea L.) in Australia. In: Spencer NR (ed) Proceedings of the X International Symposium on Biological Control of Weeds 1999, Montana, pp 67-79

Miles PW, Oertli JJ (1993) The significance of antioxidants in the aphid-plant interaction: the redox hypothesis. Entomol Exp Appl 67:275-283

Moretto AS, Distel RA (1998) Requirement of vegetation gaps for seedling establishment of two unpalatable grasses in a native grassland of central Argentina. Aust J Ecol 23: 419-423

Narberhaus I, Theuring C, Hartmann T, Dobler S (2003) Uptake and metabolism of pyrrolizidine alkaloids in Longitarsus flea beetles (Coleoptera: Chrysomelidae) adapted and non adapted to alkaloid containing host plants. J Comar Physiol 173:483-491

Narberhaus I, Theuring C, Hartmann T, Dobler S (2004) Time course of pyrrolizidine alkaloid sequestration in Longitarsus flea beetles (Coleoptera: Chrysomelidae). Chemoecology 14:17-23

Naumann C, Hartmann T, Ober D (2002) Evolutionary recruitment of a flavin-dependent monooxygenase for the detoxification of host plant-acquired pyrrolizidine alkaloids in the alkaloid-defended arctiid moth Tyria jacobaea. PNAS 99:6085-6090

Neumann H, Lütt S, Schleich-Seidfar C, Rabe I, Walter A, Böhling J, Böttner E, Mues B, Trede J, Werner M (2009) Umgang mit dem Jakobskreuzkraut Meiden-DuldenBekämpfen. Landesamt für Landwirtschaft, Umwelt und ländliche Räume des Landes Schleswig-Holstein (LLUR) und Deutscher Verband für Landschaftspflege e.V. (DVL) http://www.schleswigholstein.de/LLUR/DE/Startseite/PDF/ Jakobskreuzkraut.html

Onyilagha JC, Lazorko J, Gruber MY, Soroka JJ, Erlandson MA (2004) Effect of flavonoids on feeding preference and development of the crucifer pest Mamestra configurata Walker. J Chem Ecol 30:109-124

Poole AL, Cairns D (1940) Biological aspects of ragwort (Senecio jacobaea) control. Department of Scientific and Industrial Research Bulletin No. 82, Government Printer, Wellington
Prakash AS, Pereira TN, Reilly PE, Seawright AA (1999) Pyrrolizidine alkaloids in human diet. Mutat Res Genet Toxicol Environ Mutagen 443:53-67

Rag-Fork (2006) http://www.ragfork.com/ragwort.html

Roberts PD, Pullin AS (2007) The effectiveness of management interventions used to control ragwort species. Environ Manage 39:691-706

Rudd NT, McEvoy PB (1996) Local dispersal by the cinnabar moth Tyria jacobaeae. Ecol Appl 6:285-297

Sharrow SM, Mosher WD (1982) Sheep as biological control agent for tansy ragwort. J Range Manage 35:48-482

Siegrist-Maag S, Lüscher A, Suter M (2008) Sensitive reaction of ragwort (Senecio jacobaea) to cutting dates. Agrarforschung 15:338-343

Silvertown J, Smith B (1989) Mapping the microenvironment for seed germination in the field. Ann Bot 63:163-168

Sullivan J (2006) Ecological research in Senecio species and their natural enemies. http://www.mollivan.com/science/ senecios/index.php

Suter M, Lüscher A (2008) Occurrence of Senecio aquaticus in relation to grassland management. Appl Veg Sci 11: 317-324

Suter M, Siegrist-Maag S, Connolly J, Lüscher A (2007) Can the occurrence of Senecio jacobaea be influenced by management practice? Weed Res 47:262-269

Syrett P (1983) Biological control of ragwort in New Zealand: a review. Aust Weeds 2:96-101

Thompson A (1974) Herbicide effects on ragwort in pasture. Proceedings of the 25th New Zealand Weed and Pest Control Conference, pp 90-93

Thompson A (1977) Herbicides for the spot treatment of ragwort in pasture. Proceedings of the 30th New Zealand Weed and Pest Control Conference, pp 34-37

Thompson A (1983) Pasture weed control by rope wick applicator. In: Proceedings of the 36th New Zealand Weed and Pest Control Conference, pp 96-98

Thompson A, Makepeace W (1983) Longevity of buried ragwort (Senecio jacobaea) seed. New Zeal J Exp Agric 11:89-90

Thompson A, Saunders AE (1984) A comparison of 2, 4D and MCPA alone and in combination for the control of ragwort. In: Proceedings of the 37th New Zealand Weed and Pest Control Conference, pp 33-36

Thompson A, Saunders AE (1986) The effect of fertilizer on ragwort in pasture. In: Proceedings of the 39th New Zealand Weed and Pest Control Conference, pp 33-36

USDA (2010) United States Department of Agriculture Plant Database. http://plants.usda.gov:8080/java/profile?symbol= SEER5

van Dam NM, Vuister LWM, Bergshoeff C, de Vos H, van der Meijden E (1995) The 'raison d'être' of pyrrolizidine alkaloids in Cynoglossum officinale: deterrent effects against generalist herbivores. J Chem Ecol 21: $507-523$

van der Meijden E (1971) Senecio and Tyria (Callimorpha) in a Dutch dune area.A study on an interaction between a monophagous consumer and its host plant. In: den Boer PJ, Gradwell GR (eds) Dynamics of numbers in populations. Centre for Agricultural Publishing and Documentation, Wageningen, pp 390-404 
van der Meijden E, van der Waals-Kooi RE (1979) The population ecology of Senecio jacobaea in a (Netherlands) sand dune system: 1. Reproductive strategy and the biennial habit. J Ecol 67:131-153

van der Meijden E, van Wijk CAM, Kooi RE (1991) Population dynamics of the cinnabar moth (Tyria jacobaeae): oscillations due to food limitation and local extinction risks. Neth J Zool 41:158-173

Vrieling K, Soldaat LL, Smit W (1991) The influence of pyrrolizidine alkaloids of Senecio jacobaea on Tyria jacobaea, Brachycaudus cardii and Haplothrips senecionis. Neth J Zool 41:228-239

Wardle DA (1987) The ecology of ragwort (Senecio jacobaea L.) - a review. New Zeal J Ecol 10:67-76

Watt TA (1987) The biology and toxicity of ragwort (Senecio jacobaea L.) and its herbicidal and biological control. Herbage Abstr 57:1-6
Whitson TD, Hawkes B, Brown J, Humphrey D, Langland D (1986) Effect of herbicide treatments on tansy ragwort control. Research Progress Report Western Society of Weed Science, pp 53-54

Windig JJ (1991) Life cycle and abundance of Longitarsus jacobaeae (Coleoptera: Chrysomelidae), bio control agent of Senecio jacobaea. Entomophaga 36:605-618

Wiseman BR, Snook ME, Wilson RL, Isenhour DJ (1992) Allelochemical content of selected popcorn silks-effects on growth of corn earworm larvae (Lepidoptera, Noctuidae). J Econ Entomol 85:2500-2504

Wu B, Takahashi T, Kashiwagi T, Tebayashi S-I, Kim C-S (2007) New flavonoid glycosides from the leaves of Solidago altissima. Chem Pharm Bull 55:815-816 